\title{
REMARKS ON THE MORPHOLOGY AND DISTRIBUTION OF SOME RARE CENTRIC DIATOMS IN SOUTHERN BRAZILIAN CONTINENTAL SHELF AND SLOPE WATERS
}

\author{
Marinês Garcia ${ }^{1, *}$ and Clarisse Odebrecht ${ }^{2}$ \\ ${ }^{1}$ Universidade Federal de Pelotas - Departamento de Botânica - UFPel \\ (Rua Gomes Carneiro, 1 Prédio da Reitoria 96010-900 Pelotas, RS, Brasil) \\ ${ }^{2}$ Universidade Federal do Rio Grande - Instituto de Oceanografia - FURG \\ (Avenida Itália, km 8, 96201-900 Caixa Postal 474 Rio Grande, RS, Brasil)
}

*Corresponding author: marinesgarciabotanica@gmail.com

\begin{abstract}
A B S T R A C T
This paper provides information on the morphology and occurrence of extant diatoms of the family Asterolampraceae and Azpeitia species of the southernmost Brazilian continental shelf and slope waters in the Southwestern Atlantic Ocean $\left(28-34^{\circ} \mathrm{S}\right)$, under the influence of Tropical, Subtropical, Subantarctic Waters, terrestrial discharges from La Plata River and Lagoa dos Patos lagoon. Plankton was sampled ( $20 \mu \mathrm{m}$ net; vertical hauls) at the same 27 stations in winter 2005 and summer 2007. Among Asterolampraceae, Asteromphalus flabellatus was the most frequent species $(57 \%$ of samples) observed mainly in winter samples (92\%) in Subtropical Shelf Water but also under the influence of La Plata River plume (salinity <35). Lower frequencies were observed for Asterolampra marylandica, Asteromphalus elegans, Asteromphalus heptactis and Spatangidium arachne. Four species of Azpeitia were observed: A. barronii and A. neocrenulata for the first time in the South Atlantic Ocean while A. africana and A. nodulifer had already been registered in equatorial and southern areas of Brazil. All Azpeitia species were rare (19\%) in offshore samples (100-200 m depth. Remarks on the morphology based on light and scanning electron microcopy observations are provided along with their distribution in the study area.
\end{abstract}

\section{R E S UM O}

O trabalho apresenta informações morfológicas e sobre a ocorrência de diatomáceas atuais da família Asterolampraceae e de espécies de Azpeitia encontradas na plataforma continental e talude do extremo sul do Brasil no Oceano Atlântico Sul $\left(28-34^{\circ} \mathrm{S}\right)$, sob influência de Águas Tropical, Subtropical e Subantártica, bem como do aporte terrestre do Rio La Plata e da Lagoa dos Patos. O plâncton foi amostrado (rede de $20 \mu \mathrm{m}$; arrastos verticais) em 27 estações de coleta no inverno de 2005 e verão de 2007. Entre as Asterolampraceae, Asteromphalus flabellatus foi a espécie mais frequiente (57\% das amostras), principalmente nas amostras de inverno (92\%) em água Subtropical de Plataforma, mas também sob influência da pluma do Rio La Plata (salinidade <35). Asterolampra marylandica, Asteromphalus elegans, Asteromphalus heptactis and Spatangidium arachne ocorreram em menor frequência. Quatro espécies de Azpeitia foram observadas: A. barronii e A. neocrenulata, são citadas pela primeira vez para o Oceano Atlântico Sul, enquanto A. africana e A. nodulifer, já foram reportadas em áreas equatoriais e meridionais brasileiras. Todas as espécies de Azpeitia foram raras (19\%) nas amostras de alto-mar (entre as isobatas de 100-200 m). Considerações sobre a morfologia baseada em observações ao microscópio óptico e eletrônico de varredura são fornecidas juntamente com dados de distribuição das espécies na área estudada.

Descriptors: Brazil, Biogeography, New records, Asterolampraceae, Azpeitia.

Descritores: Brasil; Biogeografia; Novos registros; Asterolampraceae; Azpeitia.

\section{INTRODUCTION}

Diatoms are important planktonic primary producers in continental shelf and slope environments where they support the most productive fisheries in the world. In the open ocean a large proportion of them tend to sink from the surface and become food for deep-water organisms (ARMBRUST, 2009). Diatom production is generally related to the availability of 
light and nutrients, while the community composition and succession are also influenced by species optima of temperature and salinity (SMAYDA, 1980). As for other assemblages, diatoms are characterized by a few dominant species that form the bulk of community abundance and biomass, and many less abundant or rare species, which account for high local diversities. It was considered that the large pool of rare species with little contribution to total community abundance plays, nonetheless, an important role as 'seed bank' in the recruiting of new species under environmental change(CERMEÑO et al., 2010). This process may lead to the slow, gradual evolution of marine diatom communities on a geological time scale. According to those authors, the great potential for the dispersal of microbial plankton species confers on planktonic ecosystems the ability to hold every taxonomic unit required to ensure community recovery in check.

Information on centric species of the families Asterolampraceae (Asterolampra Ehr. and Asteromphalus Ehr.) and Hemidiscaceae (Azpeitia Peragallo) of the southern Brazilian marine shelf and slope waters is presented. The Asterolampraceae diatoms are easily identified by light microscopy and are usually reported as rare phytoplankton components; only occasionally are they observed in large numbers (CUPP, 1943; HALLEGRAEF; JEFFREY, 1984; POLAT; ISIK, 2002). They can be found in all geographical regions but occur mainly intropical and subtropical areas (ROUND et al., 1990; HERNÁNDEZ-BECERRIL, 1991), comprising three truly planktonic genera: Asterolampra with 30 species (two extant species: A. marylandica Ehr.; A. grevillei (Wallich) Greville), Asteromphalus Ehr. with 35 species (more than 17 extant species; ROUND et al., 1990; HERNÁNDEZ-BECERRIL, 1991) and Spatangidium Bréb. with one species (S. arachne Bréb.). In Brazil, seven taxa of Asterolampraceae have been recorded by Moreira-Filho et al. (1990, 1993), Procopiaket al. (2006) and Villac et al. (2008) (Asterolampra marylandica Ehr., Asteromphalusarachne (Bréb.) Ralfs; A. elegans Greville; A. flabellatus (Bréb.) Greville; A. heptactis (Bréb.) Ralfs; A. hookerii Ehr. and A. sarcophagus Wallich). However, during an annual cycle in coastal waters in the extreme south of Brazil, only Asteromphalus flabellatus and A. heptactis were observed, the former more frequent in October and December (austral spring/summer) but absent in winter because of the low water temperature $\left(14^{\circ} \mathrm{C}\right) ; A$. heptactiswas always rare (ROSA, 1982).

The genus Azpeitia has been described from fossil material and isreported to have flourished in the warm waters of the late Eocene, Oligocene and Miocence, with great diversity in the middle Miocene (FRYXELL et al., 1986). The extant planktonic species were known as Coscinodiscus until FRYXELL et al. (op. cit.) transferred to Azpeitia the slightly cylindrical to discoid diatoms with a flat valve face, one marginal ring of large, similarly shaped rimoportulae and a large nearly central nodule, later recognized as the rimoportula located on the edge of the annulus. Electron microscopy (EM) analysis is required to detect these ultra-structures.

Of the seventeen known Azpeitia species only six are extant: Azpeitiaafricana (Janisch ex Schmidt) G. Fryxell and T.P. Watkins, A. barronii Fryxell and Watkins, A. endoi (Kanaya) P.A. Sims and G. Fryxell, A. neocrenulata (Van Landingham) G. Fryxell and T.P. Watkins, A. nodulifer (Schmidt) G. Fryxell and P.A. Sims, and A. tabularis (Grunow) G. Fryxell and P.A. Sims (FRYXELL et al., 1986). The distribution of extant species tends to be tropical/subtropical except for Azpeitiatabularis, which is especially abundant in the Subantarctic Zone northwards and southwards of the Antarctic Convergence, and uncommon near ice (FRYXELL et al., 1986). In the Southwestern Atlantic Ocean, two species have been recorded in the plankton: $A$. africana (as Coscinodiscus africanus) in equatorial oceanic waters off the Northern Brazilian states of Pará and Maranhão, near the Amazon River $\left(0-2^{\circ} \mathrm{S}\right.$; WOOD, 1966), and A. nodulifer (as $C$. nodulifer) off the Paraná State coast $\left(25^{\circ} \mathrm{S}\right.$; PROCOPIAK et al., 2006). The environmental conditions under which these two species occur in Brazil are unknown. In surface sediments of the Southwestern Atlantic Ocean, A. barroni and A. noduliferconstitute tropical/ subtropical diatom assemblages (ROMERO; HENSEN, 2002).

Morphological characteristics and environmental data on extant Asterolampraceae (Asterolampra Ehr. and Asteromphalus Ehr.) and Hemidiscaceae (Azpeitia Peragallo) found in net samples from the southern Brazilian continental shelf and slope waters are presented. In this area, complex oceanographic conditions prevail in addition to the outflows of La Plata River and Lagoa dos Patos lagoon, mainly in winter. In summer, there is a greater influence of tropical waters and the presence of Subantarctic Shelf Water in deeper layers (MÖLLER et al., 2008; PIOLA et al., 2008).

\section{Material and Methods}

$$
\text { Study Area and Water Masses }
$$

The Southwestern Atlantic Ocean is within the domain of the boundary currents Brazil Current (BC) and Malvinas Current (MC) that, respectively, transport Tropical Water (TW) southward and Subantarctic Water (SAW) northward giving rise to the South Atlantic Central Water (SACW), also known as Subtropical Water (STW). On 
the continental shelf, important seasonal variations occur due to the meridional displacement of the Río de La Plata Plume Water (PPW), which forms a low salinity tongue during the austral winter reaching the latitudes of $28^{0} \mathrm{~S}$, off Santa Marta Grande Cape (SMGC), while in summer its influence remains restricted southwards of latitude $32^{0} \mathrm{~S}$, off Rio Grande (PIOLA et al., 2008; MÖLLER et al., 2008). A secondary freshwater source is the Lagoa dos Patos lagoon (PL) off Rio Grande. The PPW low salinity waters mix with the Subantarctic Shelf Water (SASW) transported northward by the Patagonian Current, and with TW transported southward forming the Subtropical Shelf Water (STSW) (MÖLLER et al., 2008; PIOLA et al., 2008).

The present study was conducted on two transections off SMGC (28 35'S) and Albardão-Chuí (AC, $33^{\circ} 45^{\prime}$ 'S) (Fig. 1) thus covering two areas with distinct oceanographic conditions in southern Brazil. A total of 27 oceanographic stations were distributed along cross-shelf transects during August/September 2005 (austral winter) and February 2007 (austral summer) on board the R.V. Atlântico Sul. Local depth ranged between $15 \mathrm{~m}$ and $600 \mathrm{~m}$ in coastal and slope waters, respectively. In situ temperature and salinity vertical profiles were measured with a Sensordata CTD at each station and these data are presented in Table 1.
Plankton Sampling and Analysis

Net plankton samples $(20 \mu \mathrm{m}$ mesh size net) were obtained by vertical hauls in the whole water column (coastal stations) or in the upper $100 \mathrm{~m}$ (shelf and slope stations) and preserved with formaldehyde $4 \%$ neutralized with hexamethylenetetramine. Glass permanent slides (two per sample) were prepared with clean oxidized material dried on cover slips and mounted with Naphrax (SIMONSEN, 1974). The whole coverslip surface was analyzed (magnification 400x) using the Zeiss Axiovert 135 optical inverted light microscope (LM) equipped with a Diagnostics Spot Insight camera for morphological analysis and measurements of the diatoms Asterolampraceae and Azpeitia species. The frequency of occurrence was estimated as a percentage of the number of stations at which each species was observed. For the scanning electron microscopy (SEM; JEOL JSM6060), cleaned valves and frustules were dried on a $16 \mathrm{~mm}$ diameter cover slip previously fixed on an aluminum stub, coated with gold at $1 \mathrm{kV}$ for $4 \mathrm{~min}$, and examined at an accelerating voltage of $15-20 \mathrm{kV}$ and working distance of $10 \mathrm{~mm}$.

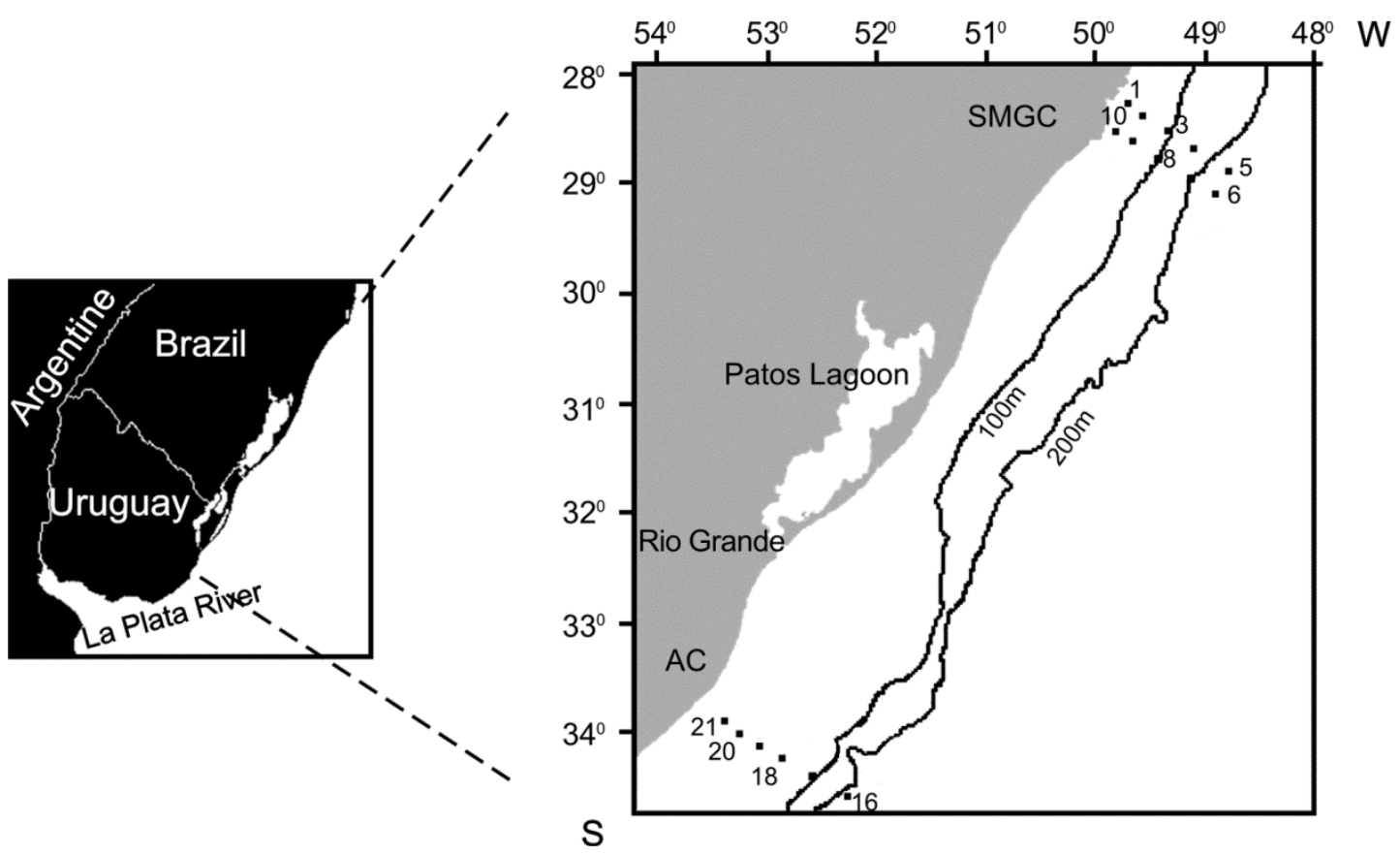

Fig. 1. Study area and stations located in the southernmost Brazilian coastal, shelf and oceanic waters off Santa Marta Grande Cape (SMGC) and Albardão-Chuí (AC). 
Table 1. Mean temperature, salinity and corresponding water mass in the upper $100 \mathrm{~m}$ at stations with records of Azpeitia and Asterolampraceae in southern Brazil.

\begin{tabular}{|c|c|c|c|c|}
\hline \multicolumn{5}{|c|}{ Period/station } \\
\hline & Depth & Temperature & Salinity & Species \\
\hline \multicolumn{5}{|c|}{ Winter } \\
\hline 1 & $0-23 \mathrm{~m}$ & 18.07 & 32.80 & A. flabellatus \\
\hline 2 & $0-60 \mathrm{~m}$ & 18.73 & 33.94 & A. flabellatus \\
\hline 3 & $0-97 \mathrm{~m}$ & 18.96 & 34.94 & A. flabellatus \\
\hline 4 & $0-100 \mathrm{~m}$ & 20.04 & 35.94 & A. flabellatus \\
\hline 5 & $0-100 \mathrm{~m}$ & 22.11 & 36.73 & $\begin{array}{l}\text { A. marylandica, A. flabellatus, } \\
\text { A. heptactis, A. africana, } A \text {. } \\
\text { neocrenulata, A. nodulifer }\end{array}$ \\
\hline 6 & $0-100 \mathrm{~m}$ & 22.52 & 36.84 & $\begin{array}{l}\text { A. flabellatus, } A \text {. africana, } A \text {. } \\
\text { barronii, } \\
\text { A. neocrenulata }\end{array}$ \\
\hline \multirow[t]{2}{*}{7} & $0-25 \mathrm{~m}$ & 19.97 & 34.92 & A. flabellatus, A. africana \\
\hline & $25-100 \mathrm{~m}$ & 20.61 & 36.36 & \\
\hline 8 & & & & A. flabellatus \\
\hline 16 & & & & A. flabellatus, A. heptactis \\
\hline \multirow[t]{3}{*}{17} & $0-35 \mathrm{~m}$ & 18.37 & 35.22 & $\begin{array}{l}\text { A. elegans, } A . \text { flabellatus, } A \text {. } \\
\text { neocrenulata }\end{array}$ \\
\hline & $35-70 \mathrm{~m}$ & 18.64 & 36.11 & \\
\hline & $70-100 \mathrm{~m}$ & 16.16 & 35.79 & \\
\hline 18 & $0-40 \mathrm{~m}$ & 15.52 & 33.61 & A. flabellatus \\
\hline 19 & $0-70 \mathrm{~m}$ & 16.58 & 34.20 & A. flabellatus \\
\hline \multicolumn{5}{|c|}{ Summer } \\
\hline \multirow[t]{2}{*}{2} & $0-20 \mathrm{~m}$ & 20.79 & 36.19 & A. flabellatus \\
\hline & $20-60 \mathrm{~m}$ & 16.32 & 35.65 & \\
\hline \multirow[t]{2}{*}{3} & $0-40 \mathrm{~m}$ & 32.78 & 36.38 & A. africana \\
\hline & $40-100 \mathrm{~m}$ & 16.96 & 35.77 & \\
\hline 6 & $1-100 \mathrm{~m}$ & 23.07 & 36,72 & $\begin{array}{l}\text { S. arachne, A. africana, } A . \\
\text { barronii, } \\
\text { A. neocrenulata, A. nodulifer }\end{array}$ \\
\hline 7 & $0-100 \mathrm{~m}$ & 22.21 & 36.55 & $\begin{array}{l}\text { S. arachne, A. africana, } A \text {. } \\
\text { neocrenulata, } \\
\text { A. nodulifer }\end{array}$ \\
\hline \multirow[t]{3}{*}{17} & $0-50 \mathrm{~m}$ & 22.46 & 34.99 & $\begin{array}{l}\text { A. heptactis, A. neocrenulata, } A \text {. } \\
\text { flabellatus }\end{array}$ \\
\hline & $50-80 \mathrm{~m}$ & 19.44 & 35.82 & \\
\hline & $80-100 \mathrm{~m}$ & 17.33 & 35.78 & \\
\hline 21 & 0-16 m & 23.80 & 33.62 & A. flabellatus \\
\hline
\end{tabular}

\section{Results}

The distribution, general morphology and valve ultrastructure details of five Asterolampraceae and four Azpeitia species observed on the southern Brazilian shelf and slope in winter (2005) and summer (2007) cruises are presented. Information on temperature and salinity at the stations is shown in Table 1.

\section{Asterolampraceae}

Asterolampra marylandica Ehrenberg, Ber. Akad. Wiss.Berlin, p. 73, 76. 1844.

Figs. 2-5.
Dimensions: diameter: $35-191 \mu \mathrm{m}$; areolae in $10 \mu \mathrm{m}$ : 12-20. Always 6 equal hyaline rays.

Remarks: The valve presents a circular outline. The rays all have the same shape and width. The dimension range is greater than that described in the literature (HUSTEDT, 1930 cited $50-150 \mu \mathrm{m}$ in diameter). Fig. 3 is in morphological agreement with Asterolampra vanheurckii Brun, which is a synonym of A. marylandica (HASLE; SYVERSTSEN, 1996). Peragalloand Peragallo (1897) illustrated $A$. marylandica var. majoras being very similar to our Fig. 3. 


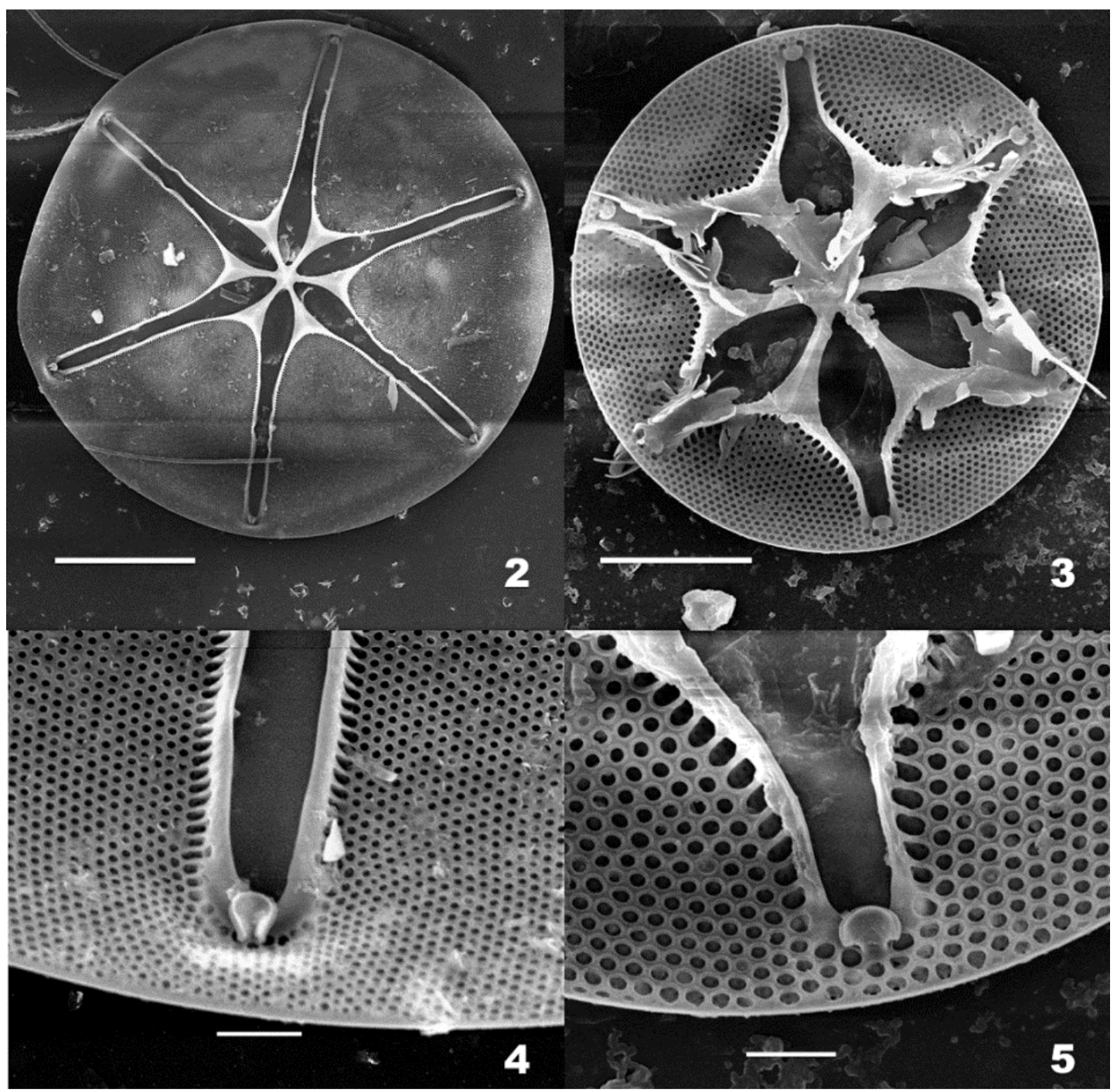

Figs. 2-5. Asterolampra marylandica. SEM images. Figs 2 and 3.General internal views. Figs 4 and 5.Details of Figs. 2 and 3, respectively. Scale bars $=50 \mu \mathrm{m}$ (Fig. 2); $10 \mu \mathrm{m}$ (Fig. 3); $5 \mu \mathrm{m}$ (Fig. 4); $2 \mu \mathrm{m}$ (Fig. 5).

Asteromphalus elegan Greville, Quart. J. micr. Sci. 7: 161, pl.7, Fig. 6. 1859.

Fig. 6.

Dimensions: diameter: $67 \mu \mathrm{m}$; areolae in $10 \mu \mathrm{m}$ : 12; Hyaline rays: 11 .

Remarks: The valve presents a quasi-circular outline. The central portion is round and extends one-half of the cell's diameter. The separating lines are slightly bent. The singular ray is thinner but has the same length as the other rays. The ordinary rays have the same width from their base to the valve's margin. The specimen studied presented 10 ordinary rays but a higher number is cited in the literature (11-26, HASLE; SYVERTSEN, 1996; 17-20, HERNÁNDEZ-
BECERRIL, 1991), and its dimension is rather smaller than those cited by Hasleand Syvertsen (1996: 100$180 \mu \mathrm{m}$ diameter). The most closely similar species $A$. flabellatus does not present the slightly bent separating lines characteristic of A. elegans.

Asteromphalus flabellatus (Brébisson) Greville, Quart. J. Micr. Sci. 7:160, pl.7, Figs. 4, 5. 1859

Figs. 7, 11, 12.

Dimensions: diameter: $64-92 \mu \mathrm{m}$; areolae in $10 \mu \mathrm{m}$ : 12-15. Hyaline rays: $10-12$.

Remarks: The valve presents a circular outline. The central portion is round, extending almost one-third of the diameter. Separating lines are straight. The 
ordinary rays are straight, wider at their base than at the valve margin. The singular ray is thinner than the ordinary rays. All the specimens observed during this study presented a circular outline and eight out of the eleven specimens studied had 10 hyaline ordinary rays. Hasle andSyvertsen (1996) illustrated $A$. flabellatusas having a circular outline, but described it as Hustedt(1930); Peragallo; Peragallo (1897); Desikachary (1988) with arounded elliptical outline. Hernandez-Becerril (1991), on the other hand, described the taxon with a subcircular or elliptical valve.

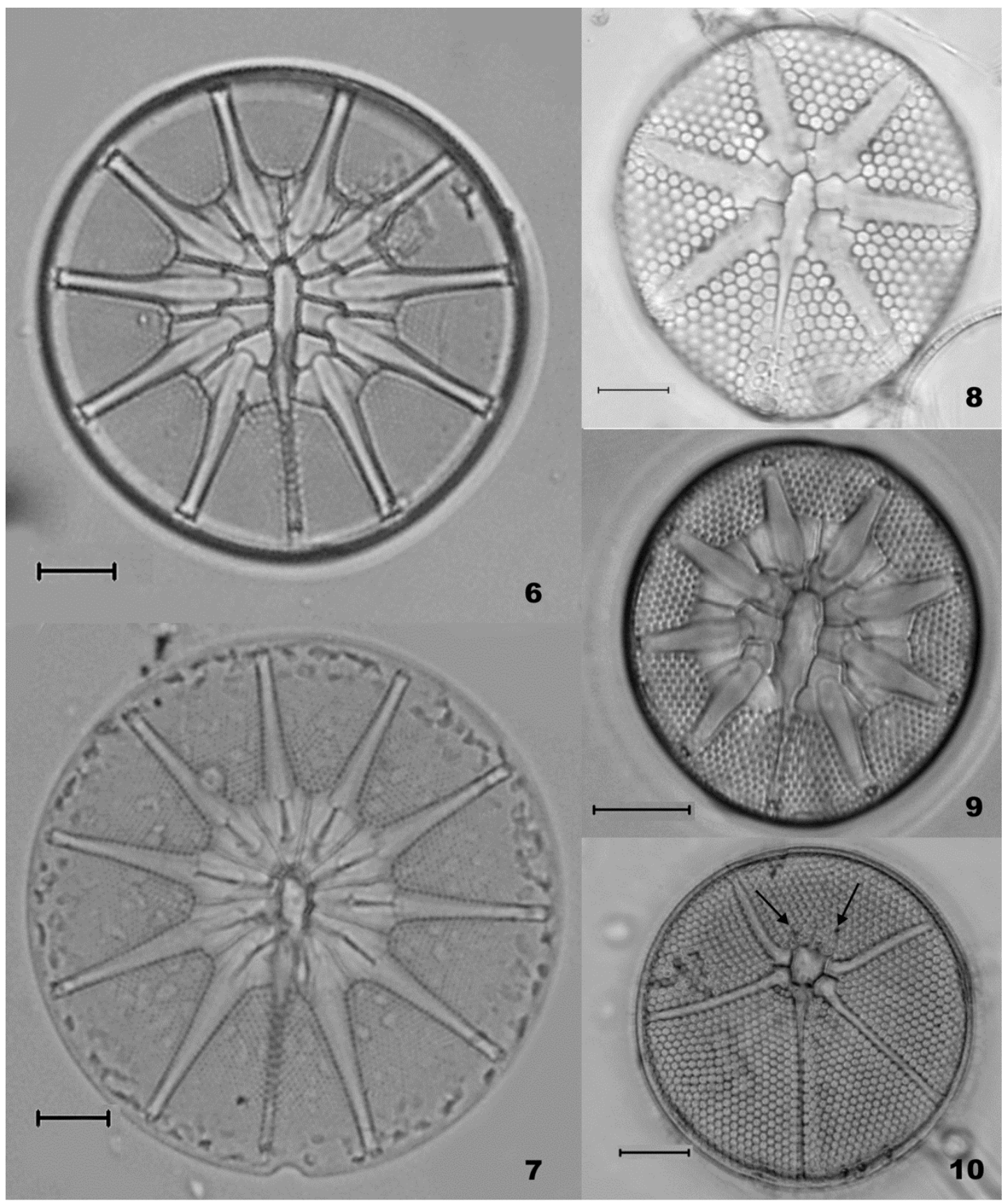

Figs 6 - 9. Asteromphalus spp. LM images. Fig. 6. A. elegans; Fig. 7. A. flabellatus; Fig. 8. A. heptactis; Fig. 9. A. robustus; Fig. 10. S. arachne, the arrows indicate rimoportulae. Scale bars $=10 \mu \mathrm{m}$. 
Asteromphalus heptactis (Brébisson) Ralfs in Pritchard, A history of the Infusoria.p. 838, pl. 8, Fig. 21. 1861.

Figs. 8, 13, 14

Dimensions: diameter: $47-55 \mu \mathrm{m}$; areolae in $10 \mu \mathrm{m}$ : 56 . Always 7 hyaline rays.

Remarks: The valve presents a subcircular outline and the separating lines a zig-zag pattern. The singular ray is thinner and longer than the others.

Asteromphalus robustus Castracane, Atti Acad Pontif. Nuovi Lincei, 28:383, pl.6, Fig. 5. 1875.
Fig. 9.

Dimensions: diameter: $37 \mu \mathrm{m}$; areolae in $10 \mu \mathrm{m}$ : 1112; 8-9 hyaline rays.

Remarks: The valve presents a subcircular to circular outline. The central portion occupies about one-half of the diameter. The separating lines are in zig-zag pattern. A. robustus presents a larger number of rays (8-10) than A. heptactis(7 rays, HERNÁNDEZBECERRIL, 1991).

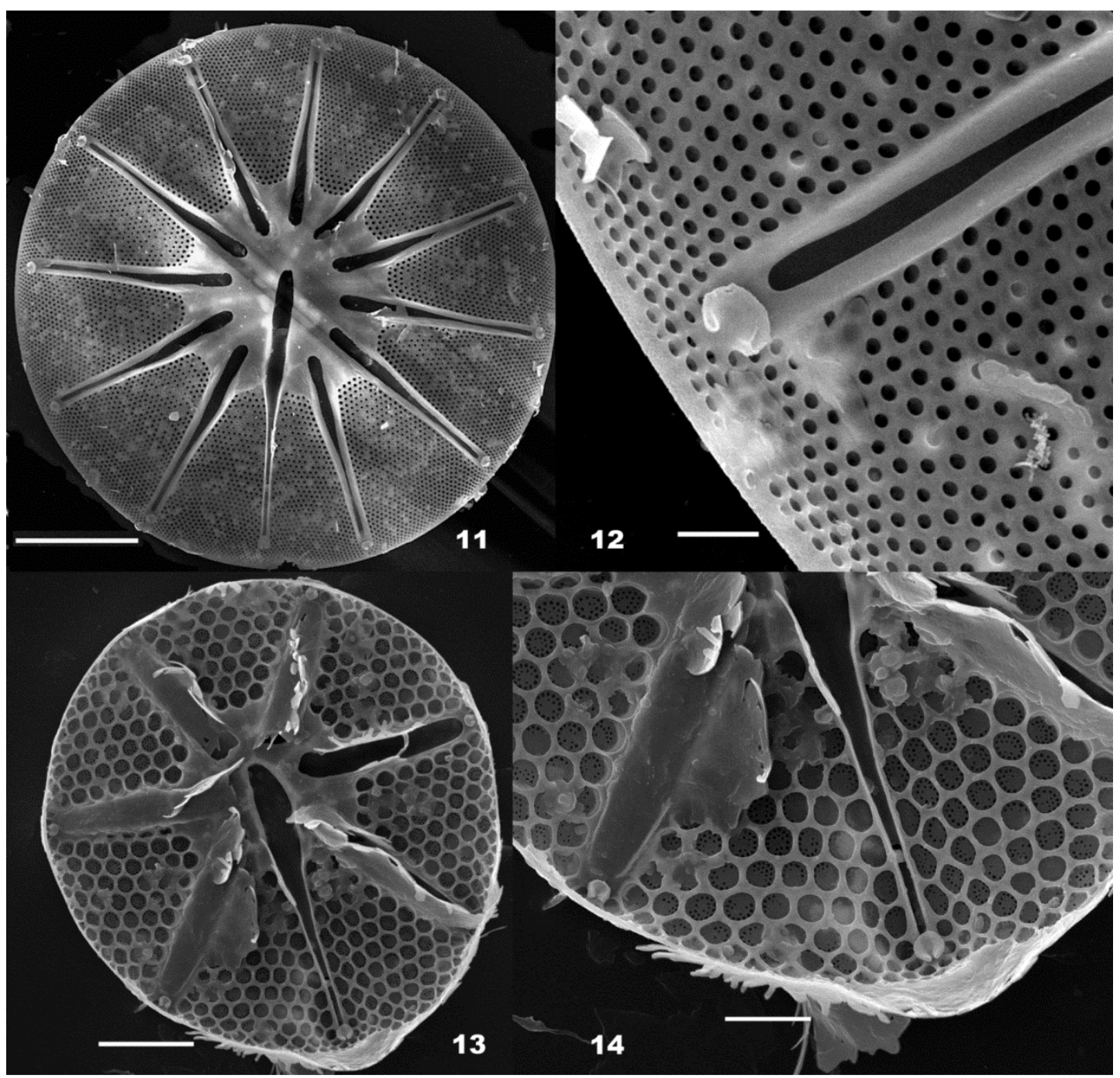

Figs 11-14. Asteromphalus spp SEM images. Figs 11-12. A. flabellatus. Figs 13-14. A. heptactis. Scale bars= $20 \mu \mathrm{m}$ (Fig. 11); $10 \mu \mathrm{m}$ (Fig. 13); $5 \mu \mathrm{m}$ (Fig. 14); $2 \mu \mathrm{m}$ (Fig. 12). 
Spatangidium arachne Brébisson, Bulletin de la Société Linneé de Normandie, 2: 296, pl. 3, Fig. 1. 1857.

Fig. 10.

Dimensions: diameter: $45-50 \mu \mathrm{m}$; areolae in $10 \mu \mathrm{m}: 8$. Always 5 hyaline rays.

Remarks: The valve presents a circular outline. The central portion is strongly excentric and the separating lines are straight. The ordinary rays are expanded at the base and are narrower, with equal widths, closer to the valve margin. The singular ray is thinner and longer than the ordinary rays. Two or three rimoportulae are present on the valve face.

Hemidiscaceae

Azpeitia africana (Janisch ex Schmidt) G. Fryxell and T.P. Watkins, Systematic Botany Monographs, 13: 22, Figs. 22, 23 and 32-1,2. 1986.

Figs. 15-19.

Dimension: diameter: $53-87 \mu \mathrm{m}$; striae in $10 \mu \mathrm{m}$ near the margin: 6-8; rimoportulae in $10 \mu \mathrm{m}: 2.16$.

Remarks: The striaepresent a decussate pattern. The taxon is easily identified in LM by the higher number of rimoportulae on one sector of the valve (see Fig. 19). The rimoportulae apertures are curved slits on the valve face's edge and can be easily observed (see Fig. 18).

Azpeitia barronii G. Fryxel and T.P. Watkins, Systematic Botany Monographs, 13: 20, Figs 28-3, 5; 19-21 and 31. 1986.

Figs. 20, 21, 27-30.

Dimension: diameter: 57-64 $\mu \mathrm{m}$; striae in $10 \mu \mathrm{m}$ near the margin: 4; rimoportulae in $10 \mu \mathrm{m}: 1.53-1.74$.

Remarks: The striae are organized in radial and sublinear rows. The areolae are surrounded by six granules (Fig. 30). The rimoportulae are found in higher number on one sector of the valve. In SEM, the external rimoportulae apertures are located on the edge of the valve face margin.

Azpeitia neocrenulata (Van Landigham) G. Fryxell and T.P. Watkins, Systematic Botany Monographs, 13: 18, Figs. 16 and 30-2. 1986.

Figs. 24-26.

Dimension: diameter: $22-50 \mu \mathrm{m}$; striae in $10 \mu \mathrm{m}$ near the margin: $11-12$ rimoportulae in $10 \mu \mathrm{m}: 1.14-1.83$.

Remarks: The areolae are organized in fascicules with a rimoportula on the valve face edge at the end of each fascicule. A diagnostic feature in LM is the mantle depressions near the rimoportulae position (Fig. 25). At the valve center the areolae are organized in a circular area surrounded by a thin hyaline ring; the central rimoportula is located just off this ring (see Fig. 26).

Azpeitia nodulifer (Schmidt) G. Fryxel and P.A. Sims. Systematic Botany Monographs, 13: 19, Figs. 17 and 30-34. 1986.

Figs. 22-23, 31-33.

Dimension: diameter: $31-55 \mu \mathrm{m}$; striae in $10 \mu \mathrm{m}$ near the margin: 5-6; rimoportulae in $10 \mu \mathrm{m}: 2.98$.

Remarks: The striae are organized in radial rows and the areolae are surrounded by six or seven granules. The rimoportulae are equally separated. In the specimens studied, the most important feature used to identify $A$. nodulifer in LM was the rimoportulae apertures located on the valve mantle with an external nodule (Fig. 23), while in SEM the presence of two rows of areolae on the mantle is characteristic of the external view (Fig. 33). Fryxell et al. (1986) had difficulty in observing the rimoportulae apertures in the valve view, but we were able to distinguish them in LM; in all the other diagnostic features the material of $A$. nodulifer studied agreed with their observations.

\section{Species Distribution}

The diatoms of the family Asterolampraceae and Azpeitia spp. were generally present in low numbers in southern Brazilian winter and summer net samples, which were prepared for diatom analysis under the light microscope. Compared to the total number of stations, the frequency of occurrence of Asterolampraceae differed in both periods, as these species were more frequently observed in the winter $(40 \%)$ than the summer samples $(10 \%)$, while the frequency of the occurrence of Azpeitia was always low (approx. 10\% in both periods). Spatially, both groups were more frequently observed in shelf slope samples (Fig. 34). Asterolampraceae and Azpeitia species were present in $50 \%$ and $30 \%$ of samples, respectively, off SMGC, as compared to AC with $30 \%$ and $6 \%$, respectively.

Three species were only found at one station: Asterolampra marylandica was observed off SMGC in winter at shelf slope station 5. Asteromphalus elegans and Asteromphalus robustus was observed in winter at shelf slope station 17 (Table $1)$.

Asteromphalus flabellatus presented a wide distribution from the coast to the shelf slope in $23 \%$ of the samples studied, mostly from the winter cruise (Fig. 34) when several valves (17) were observed off SMGC at station 7. Azpeitia africana was the only species which was also found on the shelf in summer at SMGC station 3. In winter, it was found off SMGC at stations 5, 6 and 7 and off $\mathrm{AC}$ at station 17. 

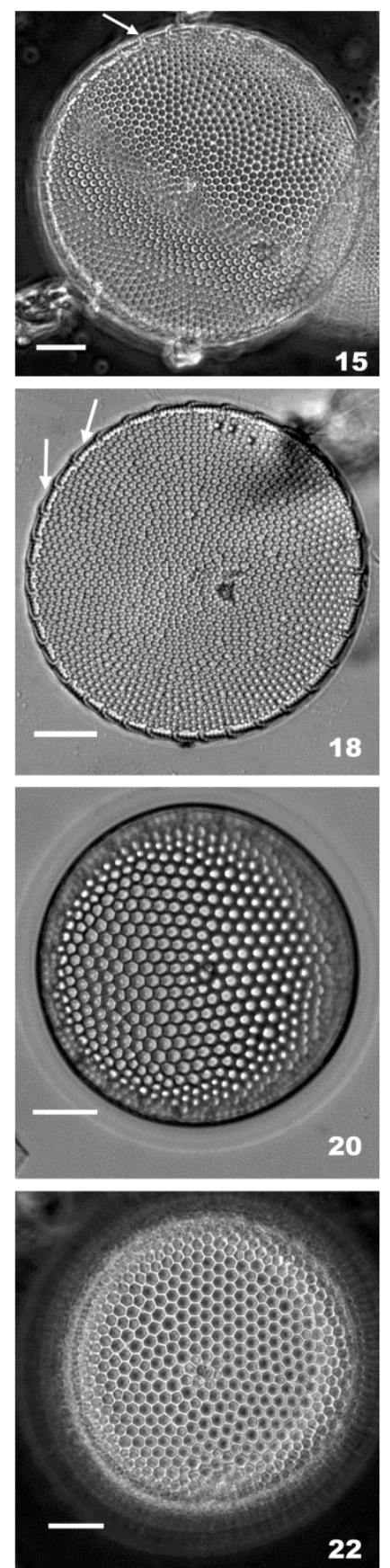
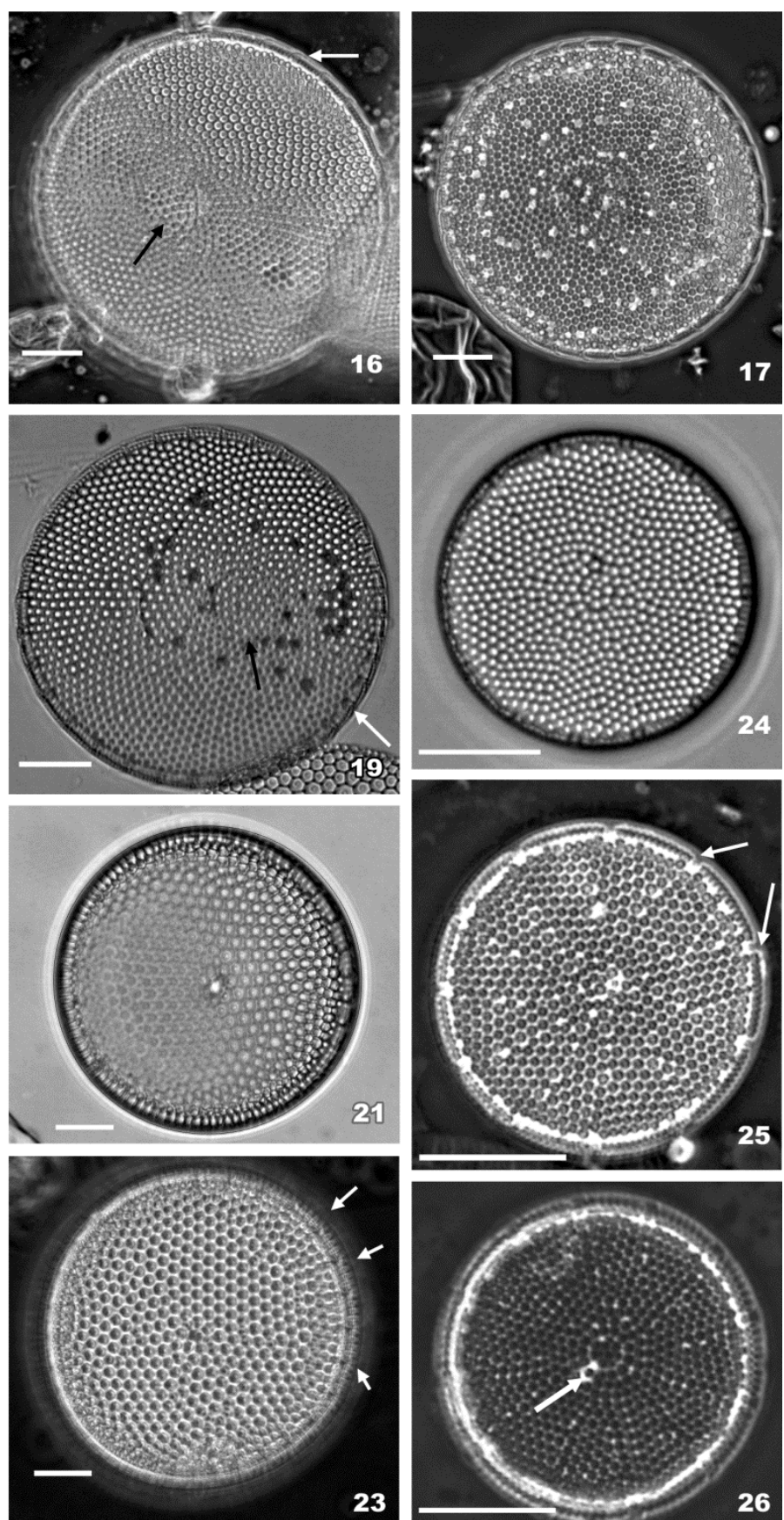

Figs 15-26. Azpeitia spp. LM images. Figs 15-19. A. africana. Figs 15 and 16. The same specimen in distinct focus. Rimoportulae apertures are indicated with white arrows. Fig. 18. On the curved aperture of rimoportulae. Fig. 19. The valve section with higher rimoportulae density is indicated with a white arrow. Figs. 16 and 19, the ring with linear areolae next to the valve centre are indicated with black arrows. Figs 20-21. A. barronii. Figs 22 -23.A. nodulifer. Fig. 23. Note the external nodules (arrowed) indicating the rimoportulae positions. Figs 24- 26. A. neocrenulata. Fig. 24. Note the areolae organized in fascicules. Fig. 25.Image taken in lower focus. Note the depressions on the mantle (arrowed). Fig. 26. Image taken in upper focus. Note the valve centre with areolae organized in a circular area surrounded by a thin circular hyaline area forming a ring and the central rimoportula (arrowed) located just off this ring. (Figs 15-16, 22-23, 25-26, Phase Contrast; Figs. 18-19, 20-21, 24, Bright field). Scale bars $=10 \mu \mathrm{m}$. 

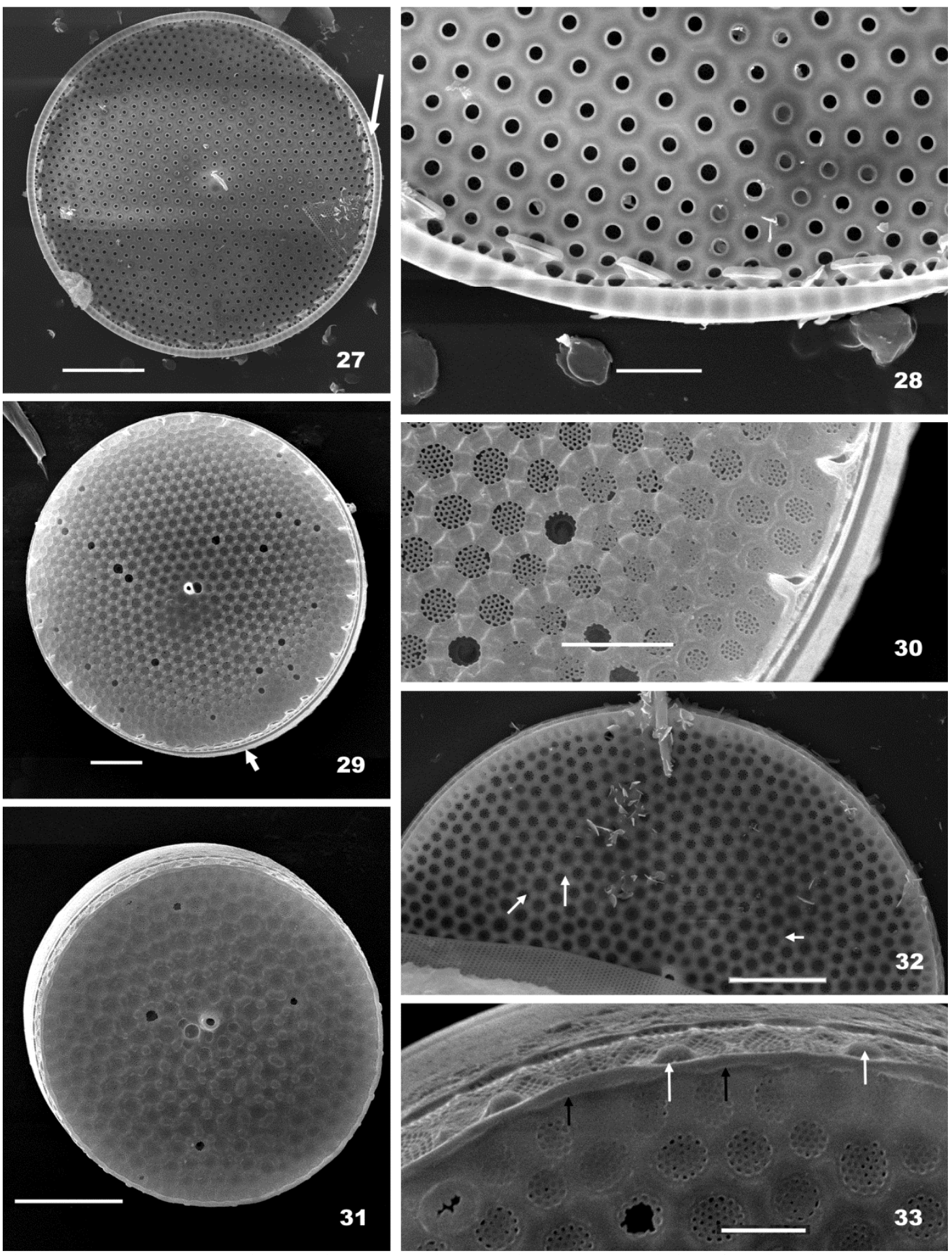

Figs 27-33. Azpeitia spp. SEM images. Figs 27-30. A. barronii. Figs 27-28. Internal view of a valve. Fig. 27. The arrow indicates the valve section with higher rimportulae density. Fig. 28. Detail of part of the valve. Note the long axis slit of the rimoportulae tilted. Figs. 29-30.External views of a valve. Fig.30. Detail of rimoportulae external apertures on the valve face. Figs 31-33. A. nodulifer.Fig. 31. External view of a frustule. Fig. 32. Partial view of a valve, showing areolae bordered by 6 and 7 granules (arrowed).Fig. 33. Partial view of a frustule (detail of Fig. 31) showing the valve face margin ridge (black arrows), presence of two rows of areolae on the mantle and the rimoportulae positioned on the mantle and its external nodules (white arrows). Scale bars: $20 \mu \mathrm{m}$ (Fig. 27); $5 \mu \mathrm{m}$ (Figs. 28, 30); $10 \mu \mathrm{m}$ (Figs 29, 31, 32); $2 \mu \mathrm{m}$ (Fig. 33). 

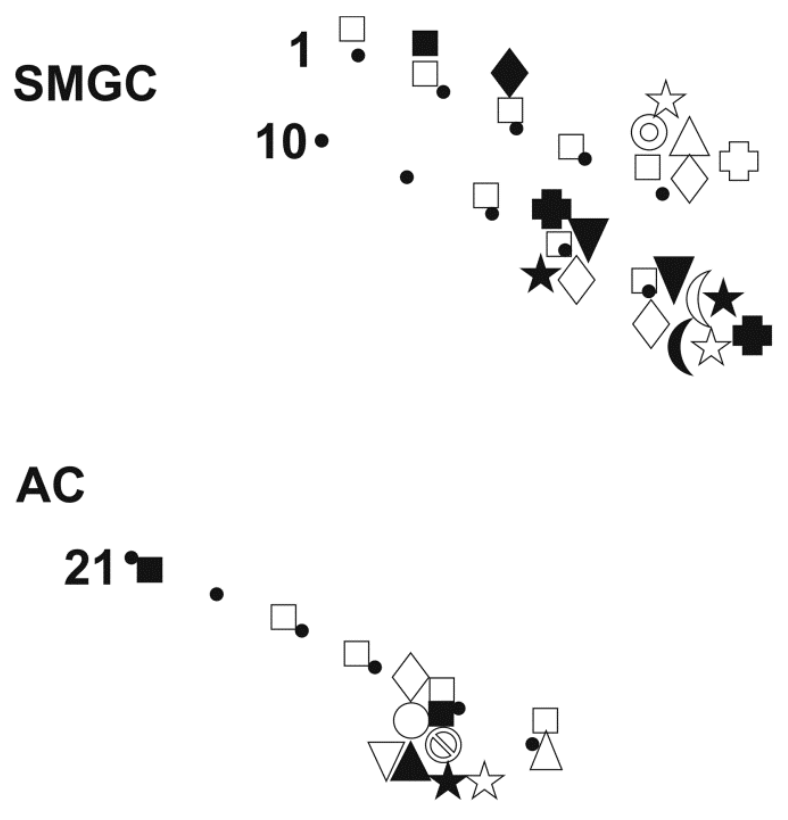

(?) Ast. marylandica

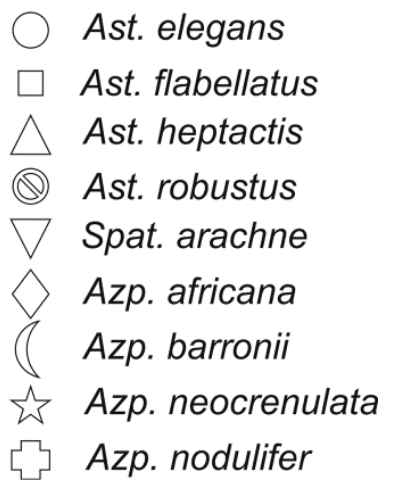

Fig. 34. Spatial distribution of species studied in summer (black) and winter (white).

Most species were found only at shelf slope stations: Asteromphalus heptactis was found in winter off SMGC (station 5) and AC (station 16) and in summer off AC (station 17). Spatangidiu marachne was found in winter off $\mathrm{AC}$ (station 17) and in summer off SMGC (stations 6 and 7). Azpeitiabarronii was found off SMGC in winter and summer at shelf slope station 6. Azpeitianeo crenulata was found off SMGC and AC in winter (stations 5, 6 and 17) and in summer (stations 6, 7 and 17). Azpeitiano dulifer was found off SMGC on the shelf slope in winter (SMGC station 5) and summer (station 6 and 7).

\section{Discussion}

The diatoms of the family Asterolampraceae and Azpeitia species were found in low numbers (generally one or two valves per slide) in southern Brazilian winter and summer net samples, as generally observed elsewhere. Only occasionally are Asterolampraceae species found in large numbers, as reported for Asteromphalus flabellatus in fall and winter (frequency of $61-100 \%$ in January) in Turkey (POLAT; ISIK, 2002) and A. heptactis off California (CUPP, 1943). In our study, A. flabellatus presented the highest frequency of occurrence and a wide spatial distribution compared to that of the other species. It was mainly observed in winter samples from nearshore to the shelf slope off both areas SMGC and $\mathrm{AC}$, with higher occurrence frequency at SMGC. Northward in Brazilian coastal waters, A. flabellatus and $A$. heptactis were found under the influence of upwelling off Cabo Frio (23 ${ }^{\circ} \mathrm{S}$; MACEDO et al., 1975; VALENTIN et al., 1985). Hernández- Becerril (1991) classified A. flabellatus as distributed worldwide in warm waters and A. heptactis as cosmopolitan. In the Southwestern Atlantic Ocean from $30^{\circ} \mathrm{S}$ to $61^{\circ} \mathrm{S}$, a plankton study was conducted in spring and A. heptactis was classified as a subtropical species with a mean proportion of ca. $0.1 \%$, while $A$. flabellatus was not mentioned (OLGUIN et al., 2006). However this species was found in Tropical/Subtropical surface sediments during several cruises in the Southwestern Atlantic together with Asteromphalus cleveanus Grunow and A. variabilis (Greville) Rattray, not found in our study, and Asterolampra marylandica and Spatangidium arachne (as Asteromphalus arachne) (ROMERO; HENSEN 2002).

Asterolampra marylandica is generally accepted as a warm water species (HASLE; SYVERSTSEN, 1996), however in Turkey, it was commonly (16-40\%) recorded in winter in waters 
within a range of between $15-18{ }^{\circ} \mathrm{C}$ (POLAT et al., 2000; POLAT, 2002). We found it only once at station 5 in winter, where Tropical Water prevailed in the upper $100 \mathrm{~m}$ of the water column.

The co-occurrence of four Azpeitia species (A. africana, A. barronii, A. neocrenulata and A. nodulifer) in oceanic waters of SMGC in summer (slope stations 5 and 6 ) is unusual in the literature. The offshore distribution of Azpeitia coincided with the prevalence of Tropical Water with high salinity (>36) and temperature $\left(>20^{\circ} \mathrm{C}\right)$ in the upper $100 \mathrm{~m}$ of the water column. These four Azpeitia species were also found in surface sediment samples collected during several cruises between $27^{\circ} \mathrm{S}$ and $50^{\circ} \mathrm{S}$ and were classified as Tropical/Subtropical by Romero and Hensen (2002). Thus the warm-water preference of Azpeitia species in southern Brazilian waters seems to confirm the biogeographical trend proposed by Fryxell et al. (1986). Temperature in the water column ranged between 16.16 and $23.92^{\circ} \mathrm{C}$, off $\mathrm{AC}$ (station 17) in winter, and off SMGC (station 3) in summer. The nutrient-rich SACW provides an important nitrogen input in the euphotic zone favoring pulses of phytoplankton growth in southern and southeastern Brazilian continental shelf and slope waters (GAETA; BRANDINI, 2006), while the Tropical Waters of the Brazil Current are well known as oligotrophic (NIENCHESKI; BAUMGARTEN 1997). The areas offshore of the Amazon mouth (WOOD, 1966) and Paraná State coastal waters (PROCOPIAK et al., 2006) are ca. $25^{\circ}$ of latitude apart and represent very different oceanographic features but it is remarkable that Azpeitia spp. were recorded in the oceanic waters in both regions.

We conclude that except for Asteromphalus flabellatus, which presented a wider spatial distribution, the diatoms of the family Asterolampraceae and of the genus Azpeitia found in southern Brazilian waters are probably warm water species. This is reinforced by the fact that they were found in Southwestern Atlantic surface sediments harboring tropical/subtropical diatom assemblages by Romero; Hensen (2002). The occurrence of four Azpeitia species at the same slope station (station 6), off Santa Marta Grande Cape under the influence of Tropical Water in winter and summer is not usual and indicates their potential as proxies for eventual oceanographic changes in southern Brazil.

\section{ACKNOWLEDGEMENTS}

The presented study was conducted with financial support from the Brazilian National Scientific and Technological Council-CNPq through the PRONEX Programme at FURG, the CNPqTaxonomy Programme and $\mathrm{CNPq}$ research fellowships granted to M. Garcia (process n. 155675/2006-0) and C. Odebrecht. The authors thank Dr. O. Möller (FURG) for making the temperature and salinity data available; the Electron Microscopy Center of the Federal University of Rio Grande do Sul for the microscopy analyzes and Miss Karina Marckmann for the technical assistance of SEM.

\section{REFERÊNCIAS}

ARMBRUST, E. The life of diatoms in the world's oceans. Nature, v. 459, p. 185-192, 2009.

CERMEÑO, P.; VARGAS, C.; ABRANTES, F.; FALKOWSKI, P.G. Phytoplankton biogeography and community stability in the Ocean.PLoS ONE, v. 5, e10037. doi:10.1371/journal.pone.0010037,2010.

CUPP, E. E. Marine plankton diatoms of the West Coast of North America.Bull. Scripps Inst. Oceanogr., v. 5, p.1$238,1943$.

DESIKACHARY, T. V. Atlas of Diatoms. v. 5. India: Madras Science Foundation, 1988. 13 p.

FRYXELL, G. A.; SIMS, P. A.; WATKINS, T. P. Azpeitia (Bacillariophyceae): related genera and promorphology. Syst. Bot. Monogr., v. 13, p.1- 74, 1986.

GAETA, S. A.; BRANDINI, F. P. Produção primária do fitoplâncton na região entre o Cabo de São Tomé (RJ) e o Chuí (RS). In: ROSSI-WONGTSCHOWSKI, C.L.; MADUREIRA, M.S.P. (Org.). O ambiente oceanográfico da plataforma continental e do talude na região Sudeste-Sul do Brasil. São Paulo: EDUSP, 2006. p. 219-264.

HALLEGRAEFF, G. M.; JEFFREY, S. W. Tropical phytoplankton species and pigments of continental shelf waters of North and North-West Australia.Mar. Ecol. Prog. Ser., v. 20, p. 59-74, 1984.

HASLE, G. R.; SYVERTSEN, E. E. Marine diatoms. In: TOMAS, C. R. (Ed.). Identifying marine Diatoms and Dinoflagellates. San Diego: Academic Press, 1996. p. 5385.

HERNANDEZ-BECERRIL, D. U. The morphology and taxonomy of species of the diatom genus Asteromphalus Her.Bibl. Diatomol., v.23, p. 1-54, 1991.

HERNÁNDEZ-BECERRIL，D. U. Reinstatement of the diatom genus Spatangidium (Bacillariophyta): the type species S. arachne. Phycologia, v. 31, p. 278-284, 1992.

HUSTEDT, F. Die Kieselalgen Deutschlands, Österreichs und der Schweizmit Berücksichtigung der übrigenLänder Europassowie der angrenzendenMeeresgebiete. 1. Dr. L. Rabenhorst's Kryptogamenflora von Deurschland, Österreich und der Schweiz. Band VII, 1930, Teil. 920 p. (Reprint 1977 by Koeltz, Koenigstein).

MACEDO, F. E.; TENENBAUM, D. R.; VALENTIN, J. Oplâncton na ressurgência de Cabo Frio, Brasil. VI. Composição florística e suas variações de comportamento nas águas da estação fixa oceânica. Período de 18/04/73 a 28/02/74. Rio de Janeiro: Instituto de Pesquisas da Marinha, v. 87, p.1-9, 1975.

MÖLLER, O. O.; PIOLA, A. R.; FREITAS, A. C.; CAMPOS, E. J. D. The effects of river discharge and seasonal winds on the shelf off southeastern South America. Cont. Shelf Res., v.28, p.1607-1624, 2008. 
MOREIRA-FILHO, H.; VALENTE-MOREIRA, I. M SOUZA-MOSIMANN. R. M.; CUNHA, J. A. Avaliação florística e ecológica das diatomáceas (Chrysophyta, Bacillariophyceae) marinhas e estuarinas nos Estados do Paraná, Santa Catarina e Rio Grande do Sul. Estud. Biol.,v. 25, p. 5-48, 1990.

MOREIRA-FILHO, H.; VALENTE-MOREIRA, I. M.; CUNHA, J. A. Estudos preliminares sobre a avaliação taxinômica e ecológica das diatomáceas (Chrysophyta Bacillariophyceae), marinhas e estuarinas nos estados de São Paulo e Rio de Janeiro, Brasil. Estud. Biol., v. 32, p. 5-52, 1993.

NIENCHESKI, L. F.; BAUMGARTEN, M. G. Environmental Chemistry. In: U. Seeliger, C. Odebrecht and J. Castello (eds.), Subtropical convergence marine ecosystem. The coast and the sea in the warm temperate southwestern atlantic, Springer Verlag, Heidelberg, pp. 20-23, 1997.

ODEBRECHT, C.; CASTELLO, J. P. The convergence ecosystem in the Southwest Atlantic. In: SEELIGER, U.; KJERFVE, B. (Ed.). Coastal marine ecosystems of Latin America. Ecol. Stud. v. 44, p. 147-165, 2001.

OLGUIN, H. F.; BOLTOWSKOY, D.; LANGE, C.; BRANDINI, F. Distribution of spring phytoplankton (mainly diatoms) in the upper $50 \mathrm{~m}$ of the Southwestern Atlantic Ocean (30-61 ${ }^{0}$ S). J. Plankton Res., v. 28, p. 1107-1128, 2006.

PERAGALlO, H.; PERAGALlO, M. Diatomées marines de France et des districts maritimesvoisins. Amsterdam: A. Asher and Co., 1897. 491 p.

PIOLA, A. R; MÖLLER- JR, O O.; GUERRERO, R. A ; CAMPOS. E. J. D. Variability of the subtropical shelf front off eastern South America: winter 2003 and summer 2004. Cont. Shelf Res., v. 28, p.1639-1648, 2008.

POLAT, S.; ISIK, O. Phytoplankton distribution, diversity and nutrients at the North-eastern Mediterranean coast of Turkey (Karataß-Adana).Turk. J. Bot., v. 26, p. 77-86, 2002.

POLAT, S.; SARIHAN, E.; KORAY. T. Seasonal changes in the phytoplankton of the Northeastern Mediterranean (Bay of Iskenderun). Turk. J. Bot., v. 24, p.1-12, 2000.
PROCOPIAK, L. K ; FERNANDES, L. F.; MOREIRAFILHO, H. Diatomáceas (Bacillariophyta) marinhas e estuarinas do Paraná, Sul do Brasil: lista de espécies com ênfase em espécies nocivas. Biota Neotrop., v. 6, $<\mathrm{http}: / / \mathrm{www}$.biotaneotropica.org.br/v6n3/pt/abstract?inv entory+bn02306032006>, 2006

ROMERO, O.; HENSEN, C. Oceanographic control of biogenic opal and diatoms in surface sediments of the Southwestern Atlantic.Mar. Geol.,v. 186, p. 263-280. 2002.

ROSA, Z. M. Diatomáceas marinhas e estuarinas de Tramandaí, Rio Grande do Sul, Brasil. Iheringia, v. 29, p. 49-145, 1982.

ROUND, F. E.; CRAWFORD, R. M.; MANN, D. G. The diatoms: Biology and morphology of thegenera. Cambridge (England); New York: Cambridge University Press, $1990.747 \mathrm{p}$.

SMAYDA, T. Phytoplankton species succession. In: MORRIS, I. (Ed.). The Physiological Ecology of phytoplankton, Berkeley: Univ. California Press, 1980. (Studies in Ecology, 7, p. 493-570).

SIMONSEN, R. The diatom plankton of the Indian Ocean Expedition of R/V "Meteor". "Meteor" Forsch.Ergebnisse, v. 19, p. 1-107, 1974

VALENTIN, J. L., LINS DA SILVA, N. M.; BASTOS, C. T. B. Lesdiatoméesdansl'upwelling de Cabo Frio (Brésil): liste d'espècesetétude écolgogique. J. Plankton Res., v. 7, p.313-337, 1985.

VILLAC, M. C.; CABRAL-NORONHA, V. A. P.; PINTO, T. O. The phytoplankton biodiversity of the coast of the state of São Paulo, Brazil. Biota Neotrop., v. 8, <http://www.biotaneotropica.org.br/v8n3/en/abstract?arti cle+bn01908032008>, 2008.

WOOD, E. J. F. A phytoplankton study of the Amazon region.Bull. Mar. Sci., v. 16, p. 102-123, 1966.

(Manuscript received 22 July 2011; revised 11 September 2012; accepted 08 October 2012) 